\title{
Advanced glycation end products impair the scavenger function of rat hepatic sinusoidal endothelial cells
}

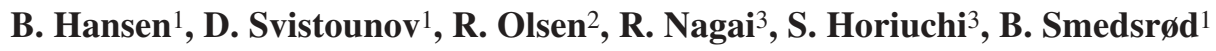 \\ ${ }^{1}$ Department of Experimental Pathology, ${ }^{2}$ Department of Electron Microscopy, Institute of Medical Biology, \\ University of Troms $\varnothing$, Troms $\varnothing$, Norway \\ ${ }^{3}$ Department of Biochemistry, Kumamoto University School of Medicine, Kumamoto, Japan
}

\section{Abstract}

Aims/hypothesis. We have previously reported that advanced glycation end products are eliminated from the circulation mainly by scavenger receptor-mediated uptake in hepatic sinusoidal endothelial cells. Our experiments showed that the degradation of AGE-modified protein after endocytosis in hepatic sinusoidal endothelial cells occurs slowly compared with that of other scavenger receptor ligands. The aim of this study was to investigate further the mechanism whereby AGEmodified protein affects the important scavenger function of hepatic sinusoidal endothelial cells.

Methods. Primary cultures of hepatic sinusoidal endothelial cells were pre-incubated with unlabelled ligand, unbound ligand was washed off, and the endocytic capacity was measured by addition of radiolabelled ligand, and immune electron microscopy.

Results. Pre-incubation with unlabelled AGE-modified bovine serum albumin reduced subsequent endocytosis of radiolabelled scavenger receptor ligands AGE-modified bovine serum albumin, formaldehydetreated serum albumin, oxidized low density lipoprotein and acetylated low density lipoprotein by 50,56 , 32 and $20 \%$, respectively. Non-scavenger receptor- mediated endocytosis was not affected by pre-exposure to AGE-modified protein. Pre-incubation with a number of non-AGE-ligands did not affect subsequent endocytosis via any of the major endocytosis receptors in hepatic sinusoidal endothelial cells. Incubation in fresh medium for $6 \mathrm{~h}$ after pre-exposure to AGEmodified protein almost completely restored normal scavenger receptor-mediated endocytic activity. Quantitative immune electron microscopy showed that the amount of a newly described scavenger receptor for AGE-modified protein is reduced after pre-incubation with AGE-modified protein. Subcellular fractionation showed that pre-incubation with AGE-modified protein delays intracellular transport of scavenger receptor ligands.

Conclusion/interpretation. Endocytosis of AGE-modified protein leads to loss of scavenger receptors and delayed intracellular transport in hepatic sinusoidal endothelial cells. [Diabetologia (2002) 45:1379-1388]

Keywords Advanced glycation end products, hepatic sinusoidal endothelial cells, scavenger receptor mediated endocytosis, endocytic capacity, intracellular transport.
Received: 14 January 2002 / Revised: 3 June 2002

Published online: 23 August 2002

C) Springer-Verlag 2002

Corresponding author: Dr. B. Hansen, PhD, Department of Dermatology, University Medical Center Mannheim, Ruprecht-Karls University Heidelberg, 68167 Mannheim, Germany. E-mail: berit.hansen@haut.ma.uni-heidelberg.de

Abbreviations: AcLDL, Acetylated low-density lipoprotein; AGE, advanced glycation end products; $\beta$-AGA, $\beta$-acetyl- glucosaminidase; CSPG, chondroitin sulphate proteoglycan; FSA, formaldehyde-treated serum albumin; HA/S-R, hyaluronan-scavenger receptor; HAGG, heat aggregated $\gamma$-globulin; HSA, human serum albumin; KC, Kupffer cell; OxLDL, oxidized low-density lipoprotein; PINP and PIIINP, N-terminal propeptides of type I and III procollagen; SEC, hepatic sinusoidal endothelial cell; SR, scavenger receptor; TCA, trichloroacetic acid; TC, tyraminyl cellobiose. 
Hepatic sinusoidal endothelial cells (SEC) constitute the most important cellular site for elimination of soluble waste macromolecules from the circulation of terrestrial vertebrates $[1,2]$. The waste product endocytosis receptors expressed by mammalian liver SEC are divided into at least five types according to specificity of ligand binding: the hyaluronan receptor [3, $4]$, the mannose receptor $[5,6]$, the collagen $\alpha$-chain receptor [7], the Fc- $\gamma$-receptor [8], and the scavenger receptor (SR). The latter receptor eliminates physiological waste molecules such as N-terminal propeptides of types I (PINP) and III (PIIINP) procollagen [9], and nidogen [10] from the circulation. Proposed atherogenic ligands such as oxidized LDL (OxLDL) [11] and AGE [12] are also cleared by the SR of SEC. Although the presence of SR class A has been established in SEC [13, 14], the uptake of SR ligands in SEC of mice that are genetically deficient in SR class A proceeds normally $[15,16]$, suggesting that SRs different from SR class A are important for the SEC SR function. A polyclonal antibody raised against a hyaluronan binding protein in rat liver, was also shown to inhibit the endocytosis of SR-ligands in SEC in vitro, indicating that the hyaluronan receptor of SEC is functionally related to the SR [17]. Since the characterization and cloning of SR class A types I and II [18, 19], several other SRs have been identified, and a family of SRs, termed SR class A, B, C, D, E and F, has been identified. SRs are involved in cell adhesion, lipoprotein metabolism and host defence [20, 21, 22, 23, 24].

Advanced glycation end products are compounds formed by non-enzymatic irreversible binding of glucose and reactive dicarbonyl species to body proteins. Long-term incubation of proteins with glucose leads to AGE which are characterized by fluorescence, brown color, and intra- and intermolecular cross-linking. Under pathological conditions, such as diabetes, ageing, atherosclerosis and Alzheimer's disease, accumulation of AGE-modified proteins can lead to tissue damage through a variety of mechanisms. AGE receptors are found in a number of different cell types $[25,26]$, and include the receptor for AGE (RAGE) [27], galectin 3 $[28,29]$, lactoferrin-like AGE-binding protein [30, 31], SR class A [32, 33], 80K-H and oligosaccharyltranferase-48 [34, 35], CD 36 [36], and SR class B type I [37]. Until recently little was known about clearance of AGE from the body. It has been shown that AGE protein is efficiently cleared from the circulation by hepatic non-parenchymal cells [38]. In line with this finding, it was demonstrated that intravenously injected AGE protein was taken up in hepatic SEC and to a lesser extent Kupffer cells (KC) [12]. Experiments in our laboratory showed that the degradation of AGE-protein after endocytosis in SEC occurs slowly compared with that of other SR-ligands. Our aim was to investigate further the mechanism whereby AGE protein affects the important scavenger function of SEC.

\section{Materials and methods}

Materials. Na ${ }^{125}$ I, Sephadex G-25 (PD-10), $\gamma$-globulin, Gelatin Sepharose 4B, Healon (hyaluronan), and Percoll were obtained from Amersham Pharmacia Biotech (Uppsala, Sweden). Fibronectin was purified from human plasma on a column of Gelatin Sepharose 4B as described by the manufacturer. Bacterial collagenase and Complete Mini (protease inhibitor cocktail) were from Boehringer Mannheim (Mannheim, Germany); BSA, mannan, cycloheximide, digitonin, MTT (3-[4,5-Dimethylthiazol-2-yl]-2,5-diphenyltetrazolium bromide), and culture medium, RPMI 1640, supplemented with $20 \mathrm{mmol} / \mathrm{l}$ sodium bicarbonate, $0.006 \%(\mathrm{w} / \mathrm{v})$ penicillin and $0.01 \%(\mathrm{w} / \mathrm{v})$ streptomycin were from Sigma Chemical (St.Louis, Mo., USA); human serum albumin (HSA) was from Octapharma (Ziegelbrücke, Switzerland); collagen was from Collagen Biomaterials (Palo Alto, Calif., USA); culture dishes were from Falcon (Becton Dickinson, Plymouth, UK). Formaldehydetreated BSA (FSA) was prepared as described [39]. Heat aggregated $\gamma$-globulin (HAGG) was prepared by heating $\gamma$-globulin in phosphate buffered saline (PBS) at $63^{\circ} \mathrm{C}$ for $1 \mathrm{~h}$. Chondroitin sulphate proteoglycan (CSPG), prepared from bovine nasal cartilage, was donated by Dr. H. Pertoft, University of Uppsala, Sweden. LDL (d.=1.019-1.063 g/ml) was isolated by sequential ultracentrifugation of fresh plasma from normolipidaemic subjects after overnight fasting, and dialysed against $0.15 \mathrm{~mol} / 1 \mathrm{NaCl} / 1 \mathrm{mmol} / 1$ EDTA $\mathrm{pH}$ 7.4. EDTA was removed from the LDL solution by dialysis against PBS. LDL was oxidized in $5 \mu \mathrm{mol} / 1 \mathrm{CuSO}_{4}$ for $24 \mathrm{~h}$ at $37^{\circ} \mathrm{C}$. Oxidation was arrested by chilling on ice, and adding $0.5 \mathrm{~mol} / \mathrm{l}$ EDTA to a final concentration of $1 \mathrm{mmol} / \mathrm{l}$. Finally, OxLDL was concentrated, and dialysed against $0.15 \mathrm{~mol} / \mathrm{l} \mathrm{NaCl} / 5 \mathrm{mmol} / \mathrm{l}$ EDTA at $4{ }^{\circ} \mathrm{C}$. Acetylated LDL (AcLDL) was prepared by chemical modification of LDL with acetic anhydride as described [38]. Immune reagents. AGE-BSA was localized on thawed cryosections using mouse anti-AGE monoclonal antibody, clone no. 6D12 (Kumamoto Immunochemical Laboratory, Kumamoto, Japan), whose major immunological epitope is $\mathrm{N}^{\varepsilon}$-(carboxymethyl)lysine [40], and rabbit anti-cow albumin polyclonal antibody (Dako A/S, Glostrup, Denmark). Rabbit anti-SEC hyaluronan-scavenger-receptor (HA-S-R) polyclonal antibody was a kind gift from Dr. P. McCourt, University of Troms $\varnothing$, Norway. Protein A-gold complexes were purchased from Drs. G. Postuma and J.W. Slot, University of Utrecht, The Netherlands.

Animals. Male Sprague Dawley rats from Harlan (Blackthorn, Bicester, UK) were kept under controlled conditions and fed a standard diet (B \& K, Nittedal, Norway) and water ad libitum. The experimental protocols were approved by the Norwegian Ethics Committee for Research on Animals.

Preparation of AGE-BSA. AGE-BSA was prepared exactly as described [38]. Reduced AGE-BSA (rAGE-BSA) was pre-

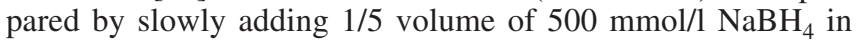
$0.5 \mathrm{~mol} / 1 \mathrm{NaH}_{2} \mathrm{PO}_{4} / \mathrm{Na}_{2} \mathrm{HPO}_{4}$ buffer $\mathrm{pH} 7.4$, and incubated for $1 \mathrm{~h}$ at room temperature. Buffer was changed to PBS by use of Vivaspin MWCO 10 kD (Vivascience, Lincoln, UK).

Labelling techniques. Proteins dissolved in PBS were labelled with 125I either by a direct reaction using Iodogen (Pierce Chemicals, Rockford, USA) as described [41] or by conjugating the protein with ${ }^{125}$ I-tyraminyl cellobiose (TC) [5]. Iodogen was used for ${ }^{125}$ I-labelling of TC. Radiolabelled protein was separated from free ${ }^{125} \mathrm{I}$ by gelfiltration through a PD-10 column and radioactivity measured in a $\gamma$-counter (Cobra II, 
Packard, Meriden, USA). The resulting specific radioactivity was approximately $25 \mathrm{kBq} / \mu \mathrm{g}$ protein (directly labelled protein) or $17 \mathrm{kBq} / \mu \mathrm{g}$ protein (125I-TC-labelled proteins). OxLDL and AcLDL were labelled with ${ }^{125} \mathrm{I}$ as described [42] to a specific radioactivity of approximately $17 \mathrm{kBq} / \mu \mathrm{g}$ protein.

Isolation and culture of liver cells. Preparation of pure cultures of functionally intact SEC from a rat liver has been described [43].

Endocytosis studies in vitro. SEC were cultured $\left(1 \times 10^{6}\right.$ cells per culture) in $2-\mathrm{cm}^{2}$ wells and maintained in serum-free RPMI 1640 medium at $37^{\circ} \mathrm{C}$ and $5 \% \mathrm{CO}_{2}$. After washing, cultures were supplied with $200 \mu \mathrm{l}$ fresh medium containing $1 \%$ (v/v) HSA, inhibitors and trace amounts (30 ng) of radiolabelled proteins. Incubations carried out for $1 \mathrm{~h}$ at $37^{\circ} \mathrm{C}$ to measure endocytosis were terminated by transferring the media, along with one wash $(500 \mu \mathrm{l})$ with PBS, to tubes containing $20 \%(\mathrm{w} / \mathrm{v})$ trichloroacetic acid (TCA) $(750 \mu \mathrm{l})$. TCA precipitates only intact protein or intermediate degradation products of high molecular weight [9]. The extent of degradation was calculated by measuring acid-soluble ligand and presented as percentage of total radioactivity. Cell-associated ligand was quantified by measuring the amount of label solubilized in $1 \%$ (w/v) SDS. Endocytosis were defined as the sum of degraded acid soluble radioactivity, and cell associated radioactivity. Experiments with cycloheximide were done by pre-incubation of SEC cultures in medium only, or medium with $100 \mu \mathrm{g} / \mathrm{ml}$ AGE-BSA for $3 \mathrm{~h}$ at $37^{\circ} \mathrm{C}$. Cells were washed and incubated with $100 \mu \mathrm{mol} / \mathrm{l}$ cycloheximide in medium or medium only for $3 \mathrm{~h}$ at $37^{\circ} \mathrm{C}$ prior to the endocytosis experiment as described. The antibody inhibition study was carried out by pre-incubation of cultured SEC with medium containing IgG from control and immune serum at indicated concentrations for $30 \mathrm{~min}$ at $37^{\circ} \mathrm{C}$ prior to endocytosis experiments as described.

MTT-assay. The cytotoxicity was analysed by an intracellular reduction of a tetrazolium salt (MTT) to a coloured formazan product which is an indicator of cell viability. Cultured SEC $\left(1 \times 10^{5}\right.$ cells per culture) in $0.3-\mathrm{cm}^{2}$ wells, were incubated with $100 \mu \mathrm{mol} / 1$ cycloheximide in medium or medium only for $3 \mathrm{~h}$ at $37^{\circ} \mathrm{C}$, washed, and incubated for $2 \mathrm{~h}$ at $37^{\circ} \mathrm{C}$ with $100 \mu \mathrm{l}$ MTT-solution (solution of $5 \mathrm{mg} / \mathrm{ml}$ was diluted 1:10 in medium). $50 \mu \mathrm{l}$ of the MTT-solution was removed, and $100 \mu \mathrm{l}$ stop solution (isopropanol with $0.04 \mathrm{M} \mathrm{HCl}$ ) was added. The plate was shaken for $30 \mathrm{~min}$, and color was measured with an ELISA reader (Novapath Mini Reader, Biorad, Oslo, Norway) at $570 \mathrm{~nm}$ with the reference filter set to $630 \mathrm{~nm}$. All MTTassays were done in triplicate.

Binding and digitonin experiment. Cultured SEC $\left(3 \times 10^{6}\right.$ cells/ culture) in $10-\mathrm{cm}^{2}$ wells were pre-incubated for $3 \mathrm{~h}$ at $37^{\circ} \mathrm{C}$ with medium only, or medium containing $100 \mu \mathrm{g} / \mathrm{ml}$ AGE-BSA, hyaluronan or FSA. Cells were washed with cold PBS and chilled before they were allowed to bind radiolabelled ligand for $1 \mathrm{~h}$ at $4^{\circ} \mathrm{C}(3 \mathrm{kBq}$ added). Cells were also treated with $0.055 \%(\mathrm{w} / \mathrm{v})$ digitonin for $10 \mathrm{~min}$ at $4^{\circ} \mathrm{C}$ before incubation with radioactive ligand. Unbound ligand was removed, and cell-associated ligand was quantified by measuring the amount of label solubilized in $1 \%(\mathrm{w} / \mathrm{v})$ SDS.

Subcellular fractionation. Cultured SEC $\left(5 \times 10^{6}\right.$ cells/culture $)$ in $28-\mathrm{cm}^{2}$ dishes were maintained in medium at $37^{\circ} \mathrm{C}$. Cultures were supplied with $1.5 \mathrm{ml}$ medium only, or medium with $100 \mu \mathrm{g} / \mathrm{ml} \mathrm{AGE-BSA}$, and pre-incubated for $3 \mathrm{~h}$ at $37^{\circ} \mathrm{C}$. After washing, the cells were pulsed with trace amounts $(17 \mathrm{kBq})$ of radiolabelled proteins for $1 \mathrm{~h}$ at $37^{\circ} \mathrm{C}$. The cells were washed, fresh medium added, and incubation continued for another $3 \mathrm{~h}$ at $37^{\circ} \mathrm{C}$. SEC were scraped off in $0.25 \mathrm{~mol} / 1$ sucrose with protease inhibitors, sonicated for $5 \mathrm{~s}$, and a postnuclear fraction was prepared by centrifugation at $1300 \times g$ for $10 \mathrm{~min}$ at $4^{\circ} \mathrm{C}$. A $4 \mathrm{ml}$ sample was layered on top of a $30 \mathrm{ml}$ linear sucrose gradient $(1.10-1.32 \mathrm{~g} / \mathrm{ml})$. After centrifugation at $76,000 \times \mathrm{g}$ in a Beckman SW28 rotor for $5 \mathrm{~h}$ at $4{ }^{\circ} \mathrm{C}$, the gradient was divided into $18 \times 2 \mathrm{ml}$ fractions by upward displacement using Maxidens (Lipotec, Liverpool, UK). The densities of the fractions were calculated from the refractive indices [44]. $\beta$-acetylglucosaminidase ( $\beta$-AGA), a lysosomal marker enzyme, was assayed fluorometrically [45].

Preparation of specimen for electron microscopy. Cultured SEC $\left(3 \times 10^{6}\right.$ cells/culture $)$ in $10-\mathrm{cm}^{2}$ dishes, were pre-incubated for $3 \mathrm{~h}$ at $37^{\circ} \mathrm{C}$ with medium only or medium with $100 \mu \mathrm{g} / \mathrm{ml}$ AGE-BSA. The cultures were fixed by adding $8 \%$ paraformaldehyde in $200 \mathrm{mmol} / 1$ HEPES pH 7.4 and stored at $4^{\circ} \mathrm{C}$. Fixed cells were gently scraped off the culture dishes and pelleted in $10 \%$ gelatin in a Microfuge E (Beckman, UK). After infusion overnight with $2.3 \mathrm{~mol} / \mathrm{l}$ sucrose the pellet was mounted on a specimen holder and frozen in $1 \mathrm{~N}_{2}$.

Immune electron microscopy. Sections were obtained from frozen pellets of SEC using an Ultracut S Ultramicrotome with an FCS cryo chamber (Leica, Vienna, Austria), and sectioned with a diamond knife (Drukker International, Cuijk, The Netherlands) at $-90^{\circ} \mathrm{C}$. The sections were retrieved in $2.3 \mathrm{~mol} / \mathrm{l} \mathrm{su}-$ crose and methylcellulose (50/50) [46], and transferred to carbon-coated grids. Immune cytochemical labelling was done as described [47]. Antibodies were detected by protein A-gold complexes. The monoclonal anti-AGE antibody 6D12 was used without a bridge between the primary antibody and protein A. A fixative block ( $1 \%$ glutaraldehyde in $\mathrm{H}_{2} \mathrm{O}$ ) between the first and second marker pair was used for double labelling. The sections were dried and examined in a JEM 1010 transmission electron microscope operating at $80 \mathrm{kV}$.

Quantitative immune cytochemistry. After pre-incubation of SEC with or without $100 \mu \mathrm{g} / \mathrm{ml} \mathrm{AGE-BSA} \mathrm{for} 3 \mathrm{~h}$ at $37^{\circ} \mathrm{C}$, the cells were washed, and supplied with medium only. After 0 and $6 \mathrm{~h}$ at $37^{\circ} \mathrm{C}$, the cells were prepared for electron microscopy. The sections, immune labelled for SEC HA-S-R, were examined in a random fashion, and for each time point $(0$ and $6 \mathrm{~h}$ ) four cell profiles were photographed at a magnification of $\times 25,000$. Gold particles were counted. The samples were immune labelled and photographed by different persons. The origin of the sample was unknown to the photographer.

Statistical analysis. The experimental data were analysed by Microsoft Excel software, and ANOVA was used for statistical analysis. Significant difference was established at a $p$ value of less than 0.05 .

\section{Results}

Effect of pre-incubation with AGE-BSA on SEC scavenger function. Endocytosis of 125I-AGE-BSA was monitored in SEC pre-incubated with AGE-BSA, hyaluronan, mannan, HAGG or collagen for $1-12 \mathrm{~h}$ at $37^{\circ} \mathrm{C}$ (Fig. 1). While pre-incubation with AGE-BSA reduced endocytosis of ${ }^{125}$ I-AGE-BSA by 28 to $53 \%$, pre-exposure to non-SR-ligands did not affect subsequent SR-mediated endocytosis of ${ }^{125} \mathrm{I}$-AGE-BSA 
Table 1. Effect of preincubation of SEC with AGE and other ligands on subsequent endocytosis via different endocytosis receptors

\begin{tabular}{|c|c|c|c|c|c|c|c|}
\hline \multirow{2}{*}{$\begin{array}{l}\text { Radiolabelled } \\
\text { ligand }\end{array}$} & \multirow[t]{2}{*}{ AGE-BSA } & \multirow[t]{2}{*}{ rAGE-BSA } & \multirow[t]{2}{*}{ FSA } & \multicolumn{4}{|c|}{ Preincubated ligand } \\
\hline & & & & Hyaluronan & Mannan & HAGG & Collagen \\
\hline 125I-FSA & $41.5 \pm 23.1^{\mathrm{a}}$ & $59.8 \pm 5.8^{b}$ & $88.1 \pm 3.9$ & & & & \\
\hline${ }^{125} \mathrm{I}-\mathrm{OxLDL}$ & $67.9 \pm 5.0^{\mathrm{b}}$ & & $111.4 \pm 3.2$ & $97.3 \pm 2.5$ & & & \\
\hline 125I-AcLDL & $81.9 \pm 5.9^{a}$ & $82.8 \pm 2.0^{\mathrm{b}}$ & $89.0 \pm 8.7$ & $94.3 \pm 15.3$ & & & \\
\hline
\end{tabular}

125I-Mannan $\quad 94.5 \pm 1.3^{\mathrm{a}}$

125I-HAGG $\quad 92.9 \pm 4.4$

125I-Collagen $\quad 99.2 \pm 1.1$

$91.1 \pm 15.9$

$94.4 \pm 7.9$

a $p<0.05$ vs control

b $p<0.001$ vs control

Cultures of SEC were preincubated with $100 \mu \mathrm{g} / \mathrm{ml}$ unlabelled ligands for $3 \mathrm{~h}$ at $37^{\circ} \mathrm{C}$, washed, and radiolabelled ligands as indicated in the table were added for $1 \mathrm{~h}$ at $37^{\circ} \mathrm{C}(n=3)$. Results, given as per cent of control \pm SEM, are means of three different experiments done in triplicate. $100 \%$ corresponds to $40-50 \%$ of added 125 I-AGE-BSA, $~ 30 \%$ of added 125 I-FSA, $\sim 20 \%$ of added ${ }^{125}$ I-OxLDL, $\sim 35 \%$ of added 125 I-AcLDL, $\sim 20 \%$ of added $125 \mathrm{I}-\mathrm{CSPG}, \sim 10 \%$ of added ${ }^{125} \mathrm{I}-$ mannan, $\sim 6 \%$ of added ${ }^{125}$ I-HAGG, and $\sim 20 \%$ of added ${ }^{125}$ I-collagen

Table 2. Dose-response effect of AGE-BSA preincubation on subsequent endocytosis of ${ }^{125} \mathrm{I}$-AGE-BSA in SEC

\begin{tabular}{cl}
\hline AGE-BSA $(\mu \mathrm{g} / \mathrm{ml})$ & Endocytosis of ${ }^{125} \mathrm{I}-\mathrm{AGE}-\mathrm{BSA}$ \\
\hline 0 & $100 \pm 0$ \\
1 & $96.0 \pm 5.7$ \\
10 & $88.8 \pm 12.9$ \\
50 & $68.5 \pm 8.4^{\mathrm{a}}$ \\
100 & $49.6 \pm 11.6^{\mathrm{b}}$ \\
\hline
\end{tabular}

a $p<0.01$ vs control

${ }^{\mathrm{b}} p<0.001$ vs control

Cultures of SEC were preincubated with $0-100 \mu \mathrm{g} / \mathrm{ml}$ AGE$\mathrm{BSA}$ for $3 \mathrm{~h}$ at $37^{\circ} \mathrm{C}$, washed, and incubation continued for another $1 \mathrm{~h}$ at $37^{\circ} \mathrm{C}$ in the presence of trace amounts of ${ }^{125} \mathrm{I}$ AGE-BSA. Results, given as per cent of control \pm SEM, are means of three different experiments done in triplicate. $100 \%$ corresponds to $40-50 \%$ of added ${ }^{125} \mathrm{I}-\mathrm{AGE}-\mathrm{BSA}$

Fig. 1. Effect of pre-incubation of SEC with ligands for different receptors on subsequent endocytosis of ${ }^{125}$ I-AGE-BSA. Cultures of SEC were pre-incubated with $100 \mu \mathrm{g} / \mathrm{ml} \mathrm{AGE-}$ BSA, hyaluronan, mannan, HAGG or collagen in medium for 1 (shaded bars), 3 (black bars), 6 (open bars), or $12 \mathrm{~h}$ (crossed bars) at $37^{\circ} \mathrm{C}$. The cells were washed, and incubation continued with trace amounts of 125 I-AGE-BSA $(500 \mathrm{~Bq})$ for $1 \mathrm{~h}$ at $37^{\circ} \mathrm{C}$. Results, given as per cent of control \pm SEM, are means of three different experiments done in triplicate. $100 \%$ corresponds to $40-50 \%$ of added ${ }^{125}$ I-AGE-BSA. ${ }^{*} p<0.01$ vs control, $* * p<0.001$ vs control

(Fig. 1). To study whether pre-loading of SEC with a specific ligand caused a general change in the scavenger capacity, we measured endocytosis of trace amounts of labelled ligands for different receptors in SEC after pre-incubation with excess amounts of unlabelled ligands for $3 \mathrm{~h}$ at $37^{\circ} \mathrm{C}$ (Table 1). While preincubation with AGE-BSA reduced endocytosis of ${ }^{125} \mathrm{I}-\mathrm{AGE}-\mathrm{BSA}$ and ${ }^{125} \mathrm{I}-\mathrm{FSA}$ by 50 and $58 \%$, endocytosis of ${ }^{125} \mathrm{I}-\mathrm{OxLDL},{ }^{125} \mathrm{I}-\mathrm{AcLDL}$ and ${ }^{125} \mathrm{I}-\mathrm{CSPG}$ was reduced by 32,18 and $42 \%$. At variance, pre-incubation with FSA reduced uptake of 125I-FSA and
125I-AcLDL by approximately $10 \%$, whereas uptake of $125 \mathrm{I}-\mathrm{OxLDL}$ was not inhibited. Reduced endocytosis caused by pre-incubation with rAGE-BSA was indistinguishable from that of AGE-BSA. Pre-exposure of SEC to unlabelled AGE-BSA, mannan, HAGG or collagen affected subsequent endocytosis of ${ }^{125}$ I-mannan, 125I-HAGG and 125I-collagen only slightly. Studies on specificity of binding of 125 I-OxLDL to SEC showed that simultaneous incubation with unlabelled AGE-BSA or FSA inhibited endocytosis by 63 and $47 \%$, respectively, while hyaluronan had no inhibitory effect. Pre-incubation of SEC with different concentrations of AGE-BSA showed a concentration dependent inhibition, with 50 and $100 \mu \mathrm{g} / \mathrm{ml}$ AGE-BSA reducing endocytosis of $125 \mathrm{I}-\mathrm{AGE}-\mathrm{BSA}$ by 31 and $50 \%$, respectively (Table 2 ).

Effect of pre-incubation with AGE-BSA on the SEC SR activity. Next we studied the effect of endocytosis of 


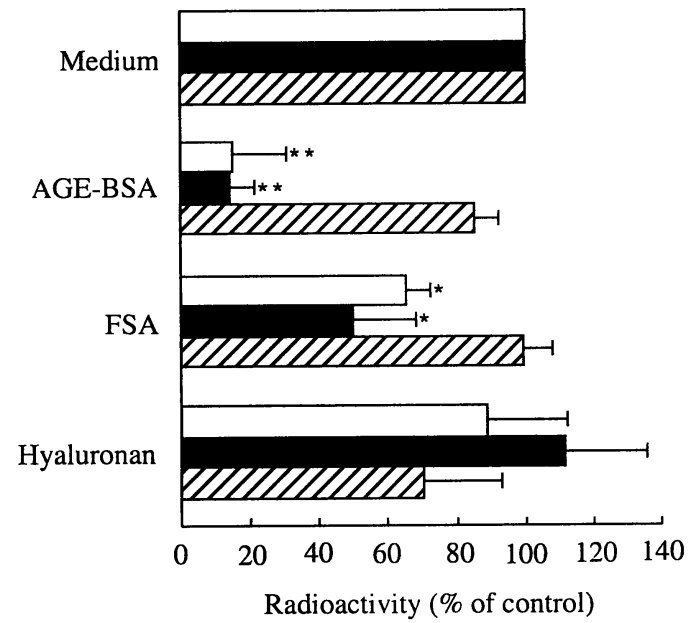

Fig. 2. Effect of pre-incubation with ligands for different receptors on subsequent binding of ${ }^{125} \mathrm{I}-\mathrm{AGE}-\mathrm{BSA}$ at $4^{\circ} \mathrm{C}$. Cultures of SEC were pre-incubated with medium only or medium with $100 \mu \mathrm{g} / \mathrm{ml}$ AGE-BSA, FSA or hyaluronan for $3 \mathrm{~h}$ at $37^{\circ} \mathrm{C}$. The cells were washed and allowed to bind 125I-AGE-BSA (open bars), 125I-FSA (black bars), or 125I-CSPG (shaded bars) for $1 \mathrm{~h}$ at $4{ }^{\circ} \mathrm{C}$. Results (cell associated radioactivity), given as per cent of control \pm SEM, are means of three different experiments done in duplicate. ${ }^{*} p<0.01$ vs control, $* * p<0.0001$ vs control

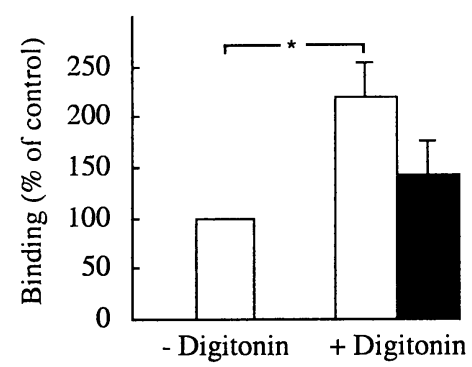

Fig. 3. Effect of digitonin. Cultures of SEC were pre-incubated in medium with (black bars) or without (open bars) $100 \mu \mathrm{g} / \mathrm{ml} \mathrm{AGE-BSA} \mathrm{for} 3 \mathrm{~h}$ at $37^{\circ} \mathrm{C}$. The cells were washed, treated with $0.055 \%$ digitonin for $10 \mathrm{~min}$ at $4^{\circ} \mathrm{C}$, and allowed to bind ${ }^{125} \mathrm{I}-\mathrm{AGE}-\mathrm{BSA}$ for $1 \mathrm{~h}$ at $4^{\circ} \mathrm{C}$. Results (cell associated radioactivity), given as per cent of control \pm SEM, are means of three different experiments done in duplicate. $* p<0.01$

AGE-BSA on the surface expression of SEC SR. Treatment of SEC with AGE-BSA reduced binding capacity of ${ }^{125}$ I-AGE-BSA and ${ }^{125}$ I-FSA by $85 \%$. Preincubation with $\mathrm{FSA}$ at $37^{\circ} \mathrm{C}$ inhibited the subsequent binding of ${ }^{125}$ I-AGE-BSA and ${ }^{125} \mathrm{I}$-FSA at $4^{\circ} \mathrm{C}$ by 34 and $50 \%$, respectively, whereas pre-incubation with hyaluronan reduced binding of $125 \mathrm{I}-\mathrm{CSPG}$ by $30 \%$ (Fig. 2). To assess the total cellular pool of receptors after pre-incubation with AGE-BSA, the cells were treated with digitonin, allowing the ligand to establish contact with intracellularly located receptors (Fig. 3). When SEC were pre-incubated with medium only, digitonin treatment resulted in a 2.2-fold increased binding of 125I-AGE-BSA compared with non-treated cells. In contrast, pre-incubation of the cells with
AGE-BSA before digitonin treatment did not increase binding of ${ }^{125} \mathrm{I}$-AGE-BSA compared with the nontreated cells. When the same type of experiment was done with ${ }^{125}$ I-collagen, digitonin treatment was observed to double the binding, which was unaffected by pre-incubation with AGE-BSA.

Effect of pre-incubation with AGE-BSA on the intracellular transport of endocytosed ligands in SEC. To study the intracellular distribution of SR-ligands in SEC we used subcellular fractionation of SEC following a $1 \mathrm{~h}$ endocytosis pulse of ${ }^{125}$ I-TC-labelled ligands. This adduct is trapped intracellularly in the organelle where degradation of the carrier protein takes place. Centrifugation of SEC homogenates in sucrose gradients showed that 125 I-TC-AGE-BSA and 125I-TC-PIIINP were associated with organelles with increasing buoyant densities (Fig. 4). In cells preincubated with medium only, ${ }^{125} \mathrm{I}-\mathrm{TC}-\mathrm{AGE}-\mathrm{BSA}$ and ${ }^{125}$ I-TC-PIIINP were distributed throughout the gradient in organelles banding at approximately $1.10,1.15$ and $1.19 \mathrm{~g} / \mathrm{ml}$ (Fig. 4A, C). After a 3-h chase the ligands were concentrated in organelles banding at approximately $1.19 \mathrm{~g} / \mathrm{ml}$ (Fig. 4B, D). When SEC were pre-incubated with AGE-BSA for $3 \mathrm{~h}$ before the $1 \mathrm{~h}$ pulse of radiolabelled ligands, ${ }^{125}$ I-TC-PIIINP was concentrated in an organelle banding at approximately $1.15 \mathrm{~g} / \mathrm{ml}$, while ${ }^{125} \mathrm{I}-\mathrm{TC}$-AGE-BSA was located in an organelle banding at approximately $1.11 \mathrm{~g} / \mathrm{ml}$ (Fig. 4A, C). After a 3-h chase the distribution of radiolabelled ligands was similar to the pattern in SEC pre-incubated with medium only (Fig. 4B, D). The intracellular distribution of ${ }^{125} \mathrm{I}$-mannan (a ligand for the mannose-receptor) was the same in SEC that had been pre-incubated with or without AGE-BSA. $\beta$-acetylglucosaminidase, a lysosomal marker enzyme, was identified at $1.2 \mathrm{~g} / \mathrm{ml}$.

Endocytosis of AGE-BSA. Studies on endocytosis of SR-ligands showed that the degradation of 125 I-AGEBSA occurs slower than that of ${ }^{125}$ I-FSA in SEC (Fig. 5). The cell-associated radioactivity after endocytosis of ${ }^{125}$ I-AGE-BSA and 125I-FSA was approximately 30 and $13 \%$ of added radioactivity after $4 \mathrm{~h}$ of incubation at $37^{\circ} \mathrm{C}$. The amount of degradation product increased with increasing incubation time, with 50 and $72 \%$ of added ${ }^{125}$ I-AGE-BSA and ${ }^{125}$ I-FSA being degraded after $4 \mathrm{~h}$ at $37^{\circ} \mathrm{C}$. To examine whether the cells could restore their endocytic ability after degradation and "wash-out" of pre-loaded AGE-BSA, we supplied cells that had been pre-incubated with AGE-BSA with fresh medium and allowed the cells to process AGE-BSA for different time periods before adding ${ }^{125} \mathrm{I}-\mathrm{AGE}-\mathrm{BSA}$ or ${ }^{125} \mathrm{I}-\mathrm{CSPG}$. With increasing incubation time in medium only, the endocytic capacity increased towards that of control cells (Fig. 6). To study whether the restored endocytic capacity was due to de novo synthesis of receptor protein, we 

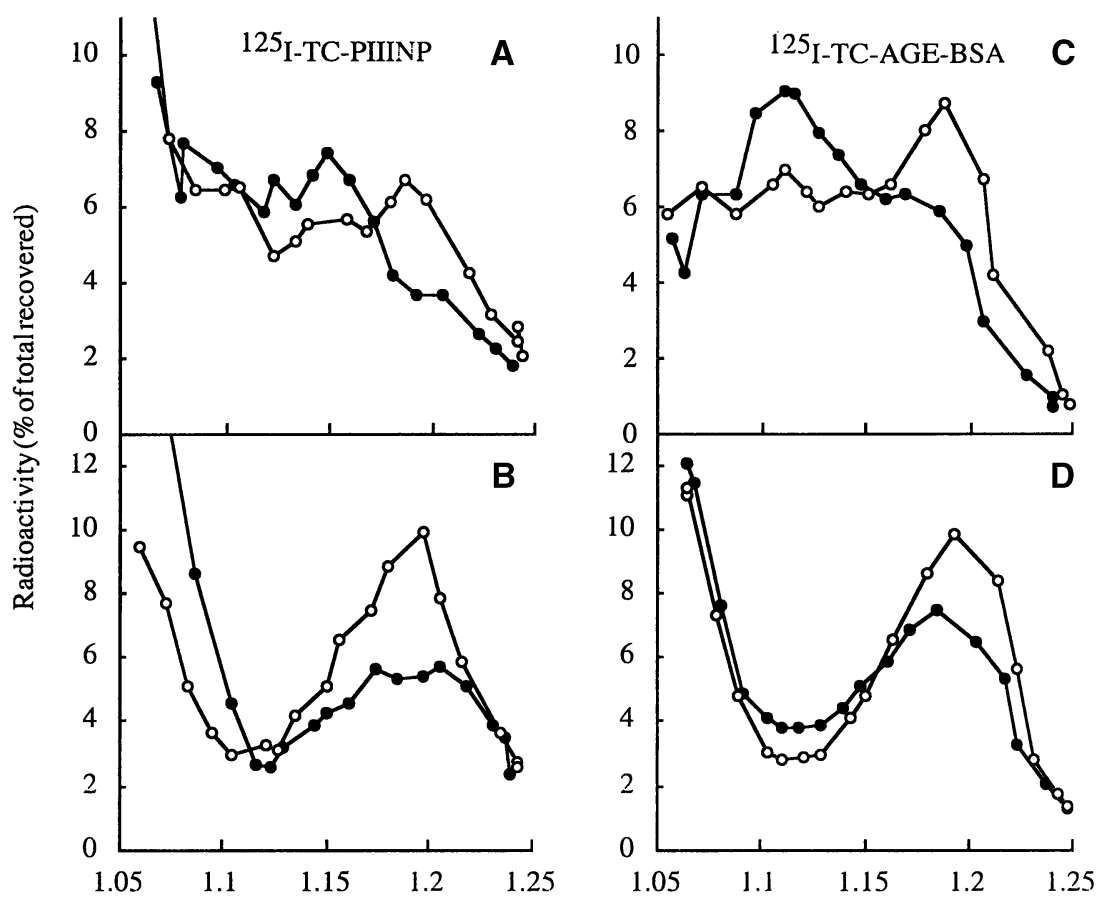

$\operatorname{Density}(\mathrm{g} / \mathrm{ml})$

Fig. 4A-D. Intracellular transport of SR-ligands in SEC. Cultures of SEC were pre-incubated with medium only (open symbols), or medium with $100 \mu \mathrm{g} / \mathrm{ml}$ AGE-BSA (filled symbols) for $3 \mathrm{~h}$ at $37^{\circ} \mathrm{C}$. The cells were washed, and incubation continued for another $1 \mathrm{~h}$ at $37^{\circ} \mathrm{C}$ in the presence of ${ }^{125} \mathrm{I}-\mathrm{TC}$-PIIINP or ${ }^{125}$ I-TC-AGE-BSA. After 0- $(\mathbf{A}, \mathbf{C})$ and 3-h $(\mathbf{B}, \mathbf{D})$ chase at $37^{\circ} \mathrm{C}$, the postnuclear fraction was fractionated in a sucrose gradient. Results are presented as \% of total recovered radioactivity in the gradient as a function of the density of the fraction. The data are representative of four independent experiments

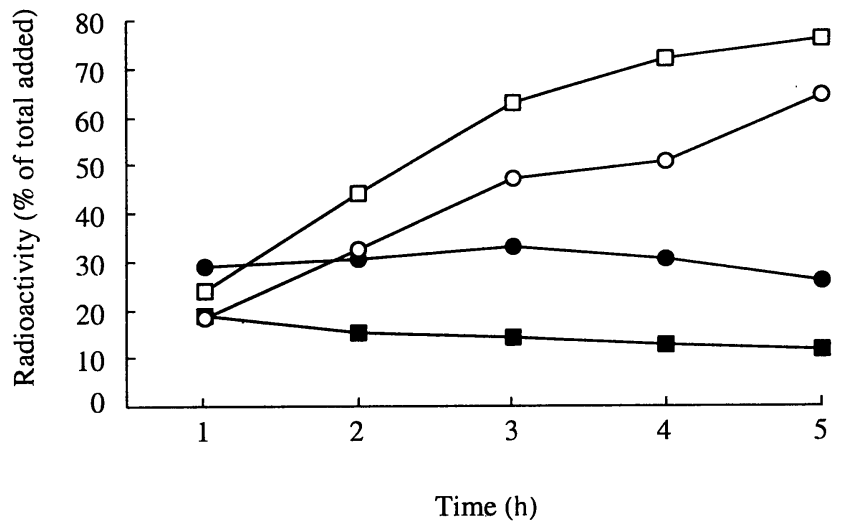

Fig. 5. Kinetics of degradation of endocytosed ${ }^{125}$ I-AGE-BSA and ${ }^{125} \mathrm{I}-\mathrm{FSA}$. Cultures of SEC were incubated with ${ }^{125} \mathrm{I}-\mathrm{AGE}-$ BSA (circles) or ${ }^{125} \mathrm{I}-\mathrm{FSA}$ (squares) for $1-5 \mathrm{~h}$ at $37^{\circ} \mathrm{C}$. The results are presented as cell-associated radioactivity (filled symbols) and acid-soluble radioactivity (open symbols). Results, given as per cent of total added radioactivity, are the mean of two different experiments performed in triplicate. Variation was $<10 \%$

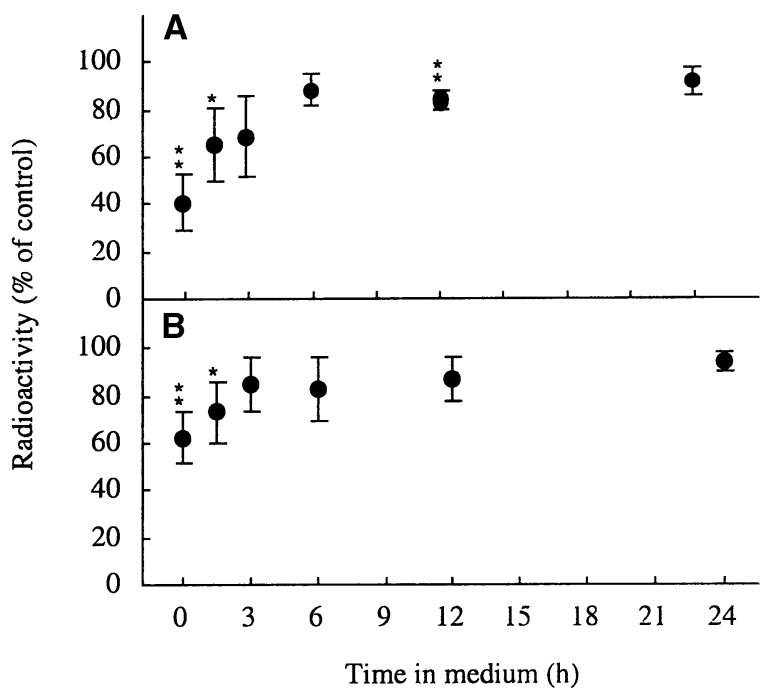

Fig. 6A, B. Rate of restoration of SR-mediated endocytosis in SEC after pre-incubation with AGE-BSA. Cultures of SEC were pre-incubated with medium only, or medium with $100 \mu \mathrm{g} / \mathrm{ml} \mathrm{AGE-BSA}$ for $3 \mathrm{~h}$ at $37^{\circ} \mathrm{C}$. The cells were washed and incubated with medium only for $0,1.5,3,6,12$ and $24 \mathrm{~h}$, before ${ }^{125}$ I-AGE-BSA (A) or ${ }^{125}$ I-CSPG (B) was added for $1 \mathrm{~h}$ $37^{\circ} \mathrm{C}$. Results, given as per cent of control \pm SEM, are means of three different experiments done in triplicate. $100 \%$ corresponds to $40-50 \%$ of added 125 I-AGE-BSA and $20 \%$ of added ${ }^{125}$ I-CSPG. ${ }^{*} p<0.05$ vs control, $* * p<0.01$ vs control

treated AGE-BSA-pre-loaded SEC with cycloheximide (Fig. 7). Although cycloheximide treatment itself inhibited endocytosis by $15 \%$, pre-incubation with AGE-BSA followed by cycloheximide treatment inhibited restoration of endocytosis by $27 \%$. Cell via- 


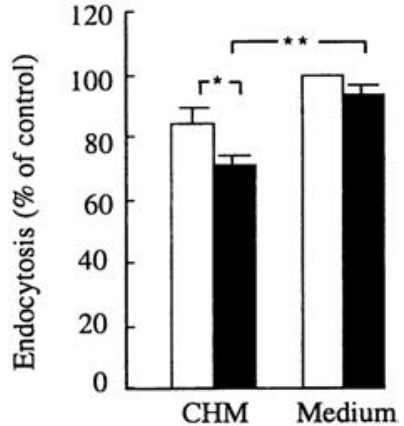

Fig. 7. Effect of cycloheximide on restoration of AGE-mediated reduced SR-endocytosis. Cultures of SEC were pre-incubated with medium only (open bars), or medium with $100 \mu \mathrm{g} / \mathrm{ml}$ AGE-BSA (black bars) for $3 \mathrm{~h}$ at $37^{\circ} \mathrm{C}$. The cells were washed, incubated with medium only or medium with $100 \mu \mathrm{mol} / 1$ cycloheximid (CHM) for $3 \mathrm{~h}$ at $37^{\circ} \mathrm{C}$, before 125I-AGE-BSA was added and incubation continued for another $1 \mathrm{~h}$ at $37^{\circ} \mathrm{C}$. Results, given as per cent of control \pm SEM, are means of three different experiments done in triplicate. $100 \%$ corresponds to $40-50 \%$ of added ${ }^{125}$ I-AGE-BSA. $* p<0.02, * * p<0.005$

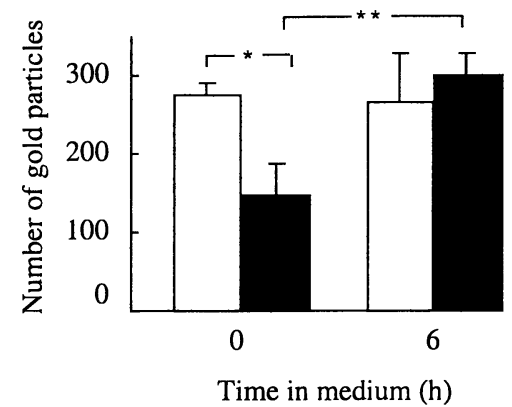

Fig. 8. Quantitative immune electron microscopy. Cultures of SEC were pre-incubated in medium only (open bars) or medium with $100 \mu \mathrm{g} / \mathrm{ml}$ AGE-BSA (black bars) for $3 \mathrm{~h}$ at $37^{\circ} \mathrm{C}$. The cells were washed, and after 0- and 6-h incubation in medium only the cells were fixed. For detection of the receptor, ultrathin cryosections were labelled with anti-SEC HA-S-R antibody and protein A-gold. For each time point $(0$ and $6 \mathrm{~h})$ four cell profiles were photographed in a random matter, and gold particles representing the receptor was counted. The samples were blinded upon labelling and counting. $* p<0.025$, $* * p<0.011$

bility of cycloheximide-treated SEC measured by MTT-assay showed that the treatment was not toxic to the cells. The pool of SRs in SEC after uptake of AGE-BSA was also examined by use of quantitative immune cytochemistry. Anti-HA-S-R-antibodies inhibited uptake of ${ }^{125} \mathrm{I}$-AGE-BSA by $44 \%$ (Table 3 ). As only approximately $10 \%$ of the IgG molecules reacts specifically, the concentration of anti-SEC HA-S-R antibodies used in this experiment was 1-100 $\mu \mathrm{g}$ protein/ml. Quantitative immune cytochemistry, using anti-SEC HA-S-R, showed that the amount of labelling in SEC after continuous uptake of AGE-BSA for $3 \mathrm{~h}$ at $37^{\circ} \mathrm{C}$ was about $50 \%$ of that observed in SEC preincubated in medium only (Fig. 8). After a 6-h incuba-

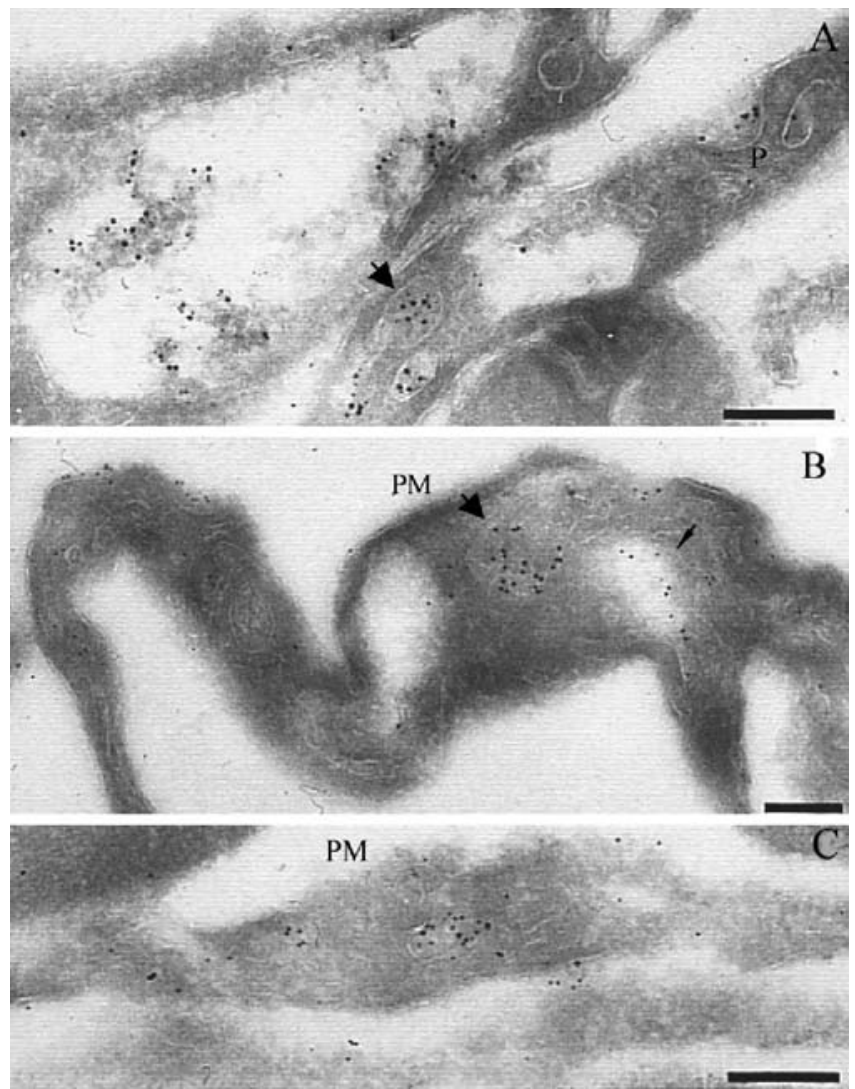

Fig. 9A-C. Immune electron microscopic localization of AGEBSA and HA-S-R in SEC. Cultures of SEC were pre-incubated with $100 \mu \mathrm{g} / \mathrm{ml} \mathrm{AGE-BSA} \mathrm{for} 3 \mathrm{~h}$ at $37^{\circ} \mathrm{C}$ and fixed immediately. For detection, thawed ultrathin cryosections were labelled with anti-AGE, anti-BSA or anti-SEC HA-S-R and protein A-gold. A Cells were double-labelled with anti-AGE (small gold) and anti-BSA (large gold); ligand is colocalized in pits $(p)$, and in intracellular electrondense (arrow) and electronlucent vesicle. B Double-labelling with anti-AGE (large gold) and anti-SEC HA-S-R (small gold) showed that AGE was located in electrondense multivesicular vesicle (large arrow), and colocalized with the receptor in an electronlucent vesicle (small arrow). AGE and HA/S-R also colocalized in pits at the plasma membrane $(\mathrm{pm})$. C Double-labelling with anti-BSA (small gold) and anti-SEC HA-S-R (large gold) showed that the receptor and ligand were colocalized. Scale mark: $200 \mathrm{~nm}$

tion in medium only, the amount of labelling of antiSEC HA-S-R was approximately equal in cells preincubated with AGE-BSA or medium only.

Electron microscopic examination of SEC pre-incubated with AGE-BSA. To visualize the intracellular transport of endocytosed AGE-BSA, SEC pre-incubated with AGE-BSA were examined by detection on thawed ultrathin cryosections by the use of anti-AGE, anti-BSA and anti-SEC HA-S-R (Fig. 9). This study showed that AGE and BSA, after $3 \mathrm{~h}$ continuous uptake of AGE-BSA, colocalized in pits at the cell surface and in intracellular electronlucent vesicles (Fig. 9A). Double-labelling for AGE and SEC HA-S-R, 
Table 3. Effect of anti-SEC HA/S-R antibodies on endocytosis of ${ }^{125}$ I-AGE-BSA

\begin{tabular}{lc}
\hline Anti SEC HA/S-Rc $(\mathrm{mg} / \mathrm{ml})$ & Endocytosis of ${ }^{125} \mathrm{I}-\mathrm{AGE}-\mathrm{BSA}$ \\
\hline 0 & 100.0 \\
0.01 & 89.8 \\
0.1 & $75.3^{\mathrm{a}}$ \\
1 & $56.0^{\mathrm{b}}$ \\
\hline
\end{tabular}

${ }^{\text {a }} p<0.05$ vs control

b $p<0.001$ vs control

Cultures of SEC were preincubated with $0-1 \mathrm{mg} / \mathrm{ml}$ anti-SEC HA-S-R for 30 min before incubation with trace amounts of ${ }^{125} \mathrm{I}-\mathrm{AGE}-\mathrm{BSA}(500 \mathrm{~Bq})$ for $1 \mathrm{~h}$ at $37^{\circ} \mathrm{C}$. Results, given as per cent of control, are the mean of two different experiments done in triplicate. Variation was less than $10 \%$. $100 \%$ corresponds to $40-50 \%$ of added ${ }^{125} \mathrm{I}-\mathrm{AGE}-\mathrm{BSA}$. Incubation with nonimmune IgG did not affect endocytosis of ${ }^{125}$ I-AGE-BSA

or BSA and SEC HA-S-R showed colocalization in pits at the cell surface and in intracellular electronlucent vesicles. AGE was also localized in a multivesicular compartment (Figs. 9B, C).

\section{Discussion}

AGE-modified proteins are eliminated from the circulation by SR-mediated endocytosis predominantly in SEC [12]. We show that endocytosis of AGE-protein reduces subsequent SR-mediated endocytic capacity in SEC. This effect of AGE-BSA is not a general inhibitory effect on the endocytic pathway, because degradation of ligands that are recognized by other receptors was only marginally affected by prior exposure of SEC to AGE-BSA. Moreover, the phenomenon cannot be explained merely as a ligand-receptor competition effect, since endocytosis experiments with radiolabelled ligands were carried out in fresh medium that contained no unlabelled AGE-BSA. These findings, along with the observation that pre-incubation with ligands specific for receptors other than SR did not affect subsequent endocytosis of radiolabelled ligands for SR or other receptors, suggest that the observed phenomenon is not caused by a cytotoxic effect of AGE-BSA. Instead, we interpret the results to mean that pre-exposure to AGE-BSA imposes a selective reduction of SR-mediated endocytosis in SEC.

Treatment of SEC with digitonin, allowing both the intracellular and cell surface pools of SR to bind ligand, showed that the cells carried an intracellular reservoir of SR amounting to about $55 \%$ of the total cellular pool, whereas $45 \%$ was located on the cell surface. Binding experiments at $4^{\circ} \mathrm{C}$ with SEC that had not been treated with digitonin (to avoid binding to intracellular SR) showed that pre-exposure to AGE-BSA reduced binding capacity by $85 \%$. Repeating the same experiment with digitonin-treated cells reduced SRbinding by $37 \%$ compared to digitonin-treated cells that had not been pre-incubated with AGE-BSA. Quantitative immune electron microscopy exposing both intracellular and surface associated pools of SR to anti-SEC HA-S-R antibody indicated that pre-incubation with AGE-BSA reduced the content of SR in SEC, confirming the results obtained by binding at $4^{\circ} \mathrm{C}$ and digitonin treatment. These observations indicate that endocytosis of AGE-BSA in SEC leads to loss of SR activity, which is the direct cause of the decreased SR-mediated endocytosis. We speculate that the cause of this receptor consumption is that AGEBSA impairs the normal mechanism for dissociation of ligand from receptor in the early endosomal compartment. The undissociated receptor-ligand complex could then travel together down the endocytic pathway, preventing the receptor from recycling to the surface. This will lead to degradation of both ligand and receptor, and thus receptor consumption. The finding that prolonged incubation $(6 \mathrm{~h})$ of SEC in AGE-BSAfree medium largely normalized the ability to endocytose AGE-BSA, along with the observation that cycloheximide inhibited this restoration, indicate that de novo protein synthesis was necessary for SR to reappear on the surface of SEC.

Subcellular fractionation of SEC has been previously used to study the intracellular transport of 125I-TC-FSA, a ligand for the SR [48, 49]. Using the same technique we observed that the SR-ligands ${ }^{125}$ I-TC-AGE-BSA and ${ }^{125}$ I-TC-PIIINP accumulated in an organelle in the early part of the endocytic pathway of SEC that had been pre-exposed to AGE-BSA. In cells that had not been pre-incubated with AGE-BSA, transport proceeded readily all the way to the lysosomes. This indicates that pre-incubation with AGE-BSA results in delayed intracellular processing of SR-ligands in SEC.

Immune electron microscopy showed that AGE and BSA colocalized in electronlucent intracellular vesicles and in pits at the cell surface, showing that the AGE adduct and the protein moiety of AGE-BSA are transported simultaneously along the endocytic pathway. Using specific markers of endocytic organelles in SEC, a report [50] showed that electronlucent vesicles carrying ligand along the inner aspect of the vesicle membrane represented early sorting endosomes, whereas electrondense vesicles, with ligand distributed throughout the lumen, represented late endosomeslysosomes. Based on these morphological criteria we observed that after a 3-h continuous uptake of AGEBSA, the AGE, BSA, and the SEC HA-S-R colocalized in electronlucent vesicles that could be characterized as early endosomes. We also observed AGE and BSA, but not HA-S-R, distributed in the lumen of electrondense vesicles defined as late endosomes-lysosomes [50]. These results show that AGE-BSA is endocytosed via receptors located in pits, with the receptor-ligand complex being transported first to early endosomes. The ligand is then transported fur- 
ther to late endosomes-lysosomes. The observation of HA-S-R in cells pre-incubated with AGE-BSA was limited to the cell surface and early endosomes. The observation that the receptor antigen colocalized with AGE or BSA at these sites, suggested that the disappearance of receptor antigen from the later parts of the endocytic pathway was due to receptor degradation rather than ligand masking. The very limited immune gold-staining of AGE or BSA at the cell surface suggested a restricted recycling of ligand. We conclude that the uptake of AGE-BSA in SEC impairs intracellular transport of SR-ligands and reduces the number of receptors for these ligands, supposedly due to their degradation in the endosomal-lysosomal compartment.

Our findings are compatible with the idea that exposure of SEC to high concentrations of AGE proteins in diabetic patients can reduce the clearance of SR ligands from the circulation. This could allow atherogenic substances (OxLDL and AGE protein, that are both SR ligands) to escape hepatic clearance, which could increase the risk of developing cardiovascular complications. The concentration of AGE-BSA used in this study is higher than what would be expected in a physiological situation, therefore our experimental system might not be adequate. However, in patients with even slightly increased concentrations of AGE in the circulation, SEC will be constantly supplied with AGE proteins, allowing high concentrations of intracellularly accumulated AGE. Accordingly, the blood plasma concentration of AGE can be considerable lower than in the presently described in vitro system, and yet lead to a marked exposure of SEC to AGE.

Acknowledgements. This study was supported by The Norwegian Research Council (grant no. 114495/310).

\section{References}

1. Smedsrød B, Pertoft H, Gustafson S, Laurent TC (1990) Scavenger function of the liver endothelial cell. Biochem J 266:313-327

2. Smedsrød B, Seternes T, Sørensen K, Lindhe Ö, Sveinbjörnsson B (1999) Scavenger endothelial cells. Cells Hep Sinus 7:147-152

3. Smedsrød B, Pertoft H, Eriksson S, Fraser J, Laurent T (1984) Studies in vitro on the uptake and degradation of sodium hyaluronate in rat liver endothelial cells. Biochem J 223:617-626

4. Smedsrød B, Kjellen L, Pertoft H (1985) Endocytosis and degradation of chondroitin sulphate by liver endothelial cells. Biochem J 229:63-71

5. Smedsrød B, Melkko J, Risteli L, Risteli J (1990) Circulating C-terminal propeptide of type I procollagen is cleared mainly via the mannose receptor in liver endothelial cells. Biochem J 271:345-350

6. Smedsrød B, Tollersrud O (1995) Sinusoidal liver endothelial cells recruit lysosomal enzymes from the circulation by mannose-receptor mediated endocytosis. Cells Hep Sinus 5:180-183
7. Smedsrød B, Johansson S, Pertoft H (1985) Studies in vivo and in vitro on the uptake and degradation of soluble collagen $\alpha 1(\mathrm{I})$ chains in rat liver endothelial cells and Kupffer cells. Biochem J 228:415-424

8. Løvdal T, Andersen E, Brech A, Berg T (2000) Fc receptor mediated endocytosis of small soluble immunoglobulin $G$ immune complexes in Kupffer and endothelial cells from rat liver. J Cell Sci 113:3255-3266

9. Melkko J, Hellevik T, Risteli L, Risteli J, Smedsrød B (1994) Clearance of $\mathrm{NH}_{2}$-terminal propeptides of type I and III procollagen is a physiological function of the scavenger receptor in liver endothelial cells. J Exp Med 179:405-412

10. Smedsrød B, Melkko J, Mayer U, Johansson S (1997) Nidogen is a physiological ligand for the scavenger receptor in liver enothelial cells. Atherosclerosis 134:362

11. Nagelkerke F, Havekes L, van Hinsbergh VWM, van Berkel TJC (1984) In vivo and in vitro catabolism of native and biologically modified LDL. FEBS Lett 171:149153

12. Smedsrød B, Melkko J, Araki N, Sano H, Horiuchi S (1997) Advanced glycation end products are eliminated by scavenger-receptor-mediated endocytosis in hepatic sinusoidal Kupffer and endothelial cells. Biochem J 322:567573

13. Hughes DA, Fraser IP, Gordon S (1995) Murine macrophage scavenger receptor: in vivo expression and function as receptor for macrophage adhesion in lymphoid and nonlymphoid organs. Eur J Immunol 25:466-473

14. Juvet L, Løvdal T, Kjeken R, Berg T, Gjøen T (1999) Role of receptors and endocytosis in hepatic sinusoidal cells. Cells Hep Sinus 7:43-48

15. Van Berkel TJC, Van Velzen A, Kruijt JK, Suzuki H, Kodama T (1998) Uptake and catabolism of modified LDL in scavenger-receptor class A type I/II knock-out mice. Biochem J 331:29-35

16. Matsumoto K, Sano H, Nagai R et al. (2000) Endocytic uptake of advanced glycation end products by mouse liver sinusoidal endothelial cells is mediated by a scavenger receptor distinct from the macrophage scavenger receptor class A. Biochem J 352:233-240

17. McCourt PA, Smedsrød BH, Melkko J, Johansson S (1999) Characterization of a hyaluronan receptor on rat sinusoidal liver endothelial cells and its functional relationship to scavenger receptors. Hepatology 30:1276-1286

18. Kodama T, Freeman M, Rohrer L, Zabrecky J, Matsudaira P, Krieger M (1990) Type I macrophage scavenger receptor contains $\alpha$-helical and collagen-like coiled coils. Nature 343:531-535

19. Rohrer L, Freeman M, Kodama T, Penman M, Krieger M (1990) Coiled-coil fibrous domains mediate ligand binding by macrophage scavenger receptor type II. Nature 343: $570-572$

20. Krieger M (1997) The other side of scavenger receptors: pattern recognition for host defence. Curr Opin Lipidol 8:275-280

21. Platt N, Gordon S (1998) Scavenger receptors: diverse activites and promiscuous binding of polyanionic ligands. Chem Biol 5:R193-R203

22. Greaves DR, Gough PJ, Gordon S (1998) Recent progress in defining the role of scavenger receptors in lipid transport, atherosclerosis and host defence. Curr Opin Lipidol 9:425-432

23. Terpstra V, van Amersfoort ES, van Velzen AG, Kuiper J, van Berkel TJC (2000) Hepatic and extrahepatic scavenger receptors: function in relation to disease. Arterioscler Thromb Vasc Biol 20:1860-1872 
24. Zingg JM, Ricciarelli R, Azzi A (2000) Scavenger receptors and modified lipoproteins: fatal attractions? IUBMB Life 49:397-403

25. Raj DS, Choudhury D, Welbourne TC, Levi M (2000) Advanced glycation end products: a Nephrologist's perspective. Am J Kidney Dis 35:365-380

26. Singh R, Barden A, Mori T, Beilin L (2001) Advanced glycation end-products: a review. Diabetologia 44:129-146

27. Schmidt AM, Yan SD, Yan SF, Stern DM (2000) The biology of the receptor for advanced glycation end products and its ligands. Biochim Biophys Acta 1498:99-111

28. Pricci F, Leto G, Amadio L et al. (2000) Role of galectin-3 as a receptor for advanced glycosylation end products. Kidney Int 58 [Suppl 77]:S31-S39

29. Zhu W, Sano H, Nagai R, Fukuhara K, Miyazaki A, Horiuchi S (2001) The role of galectin-3 in endocytosis of advanced glycation end products and modified low density lipoproteins. Biochem Biophys Res Commun 280:11831188

30. Schmidt AM, Vianna M, Gerlach M et al. (1992) Isolation and characterization of two binding proteins for advanced glycosylation end products from bovine lung which are present on the endothelial cell surface. J Biol Chem 267:14987-14997

31. Schmidt AM, Mora R, Cao R et al. (1994) The endothelial cell binding site for advanced glycation end products consists of a complex: an integral membrane protein and lactoferrin-like polypeptide. J Biol Chem 269:9882-9888

32. Araki N, Higashi T, Mori T et al. (1995) Macrophage scavenger receptor mediates the endocytic uptake and degradation of advanced glycation end products of the Maillard reaction. Eur J Biochem 230:408-415

33. Suzuki H, Kurihara Y, Takeya M et al. (1997) A role for macrophage scavenger receptors in atherosclerosis and susceptibility to infection. Nature 386:292-296

34. Li YM, Mitsuhashi T, Wojciechowicz D et al. (1996) Molecular identity and cellular distribution of advanced glycation endproduct receptors: relationship of p60 to OST-48 and p90 to $80 \mathrm{~K}-\mathrm{H}$ membrane proteins. Proc Natl Acad Sci USA 93:11047-11052

35. Thornalley PJ (1998) Cell activation by glycated proteins. AGE receptors, receptor recognition factors and functional classification of AGEs. Cell Mol Biol 44:1013-1023

36. Ohgami N, Nagai R, Ikemoto M et al. (2001) CD36, a member of class B scavenger receptor family, as a receptor for advanced glycation end products (AGE). J Biol Chem 276:3195-3202

37. Ohgami N, Nagai R, Miyazaki A et al. (2001) Scavenger receptor class B type I-mediated reverse cholesterol trans- port is inhibited by advanced glycation end products. J Biol Chem 276:13348-13355

38. Takata K, Horiuchi S, Araki N, Shiga M, Saitoh M, Morino Y (1988) Endocytic uptake of nonenzymatically glycosylated proteins is mediated by a scavenger receptor for aldehyde-modified proteins. J Biol Chem 263:1481914825

39. Mego JL, Bertini F, McQueen JD (1967) The use of formaldehyde-treated ${ }^{131} \mathrm{I}$-albumin in the study of digestive vacuoles and some properties of these particles from mouse liver. J Cell Biol 32:699-707

40. Ikeda K, Higashi T, Sano H et al. (1996) $\mathrm{N}^{\varepsilon}$-(carboxymethyl)lysine protein adduct is a major immunological epitope in proteins modified with advanced glycation end products of the Maillard reaction. Biochemistry 35:80758083

41. Markwell MAK (1982) A new solid-state reagent to iodonate proteins. I. Conditions for the efficient labeling of antiserum. Anal Biochem 125:427-432

42. McFarlane AS (1958) Efficient trace-labelling of proteins with iodine. Nature 182:53

43. Pertoft H, Smedsrød B (1987) Separation and characterizaton of liver cells. In: Pretlow TG, Pretlow TP (eds) Cell Separation: Methods and selected applications. Vol 4, Academic Press, New York, pp 1-24

44. Rickwood D (1983) Iodonated density gradient media a practical approach. In: Rickwood D (ed) Iodonated density gradient media - a practical approach. IRL press, Oxford, pp 1-21

45. Barrett A, Heath M (1972) Lysosomal enzymes. In: Dingle J (ed) Lysosomes - a laboratory handbook. NorthHolland publishing company, Amsterdam, pp 111-125

46. Liou W, Geuze HJ, Slot JW (1996) Improving structural integrity of cryosections for immunogold labeling. Histochem Cell Biol 106:41-58

47. Griffith G (1993) Fine structure immuncytochemistry. Springer Verlag, Berlin Heidelberg

48. Eskild W, Kindberg GM, Smedsrød B, Blomhoff R, Norum KR, Berg T (1989) Intracellular transport of formaldehyde-treated serum albumin in liver endothelial cells after uptake via scavenger receptors. Biochem J 258:511520

49. Kindberg GM, Stang E, Andersen KJ, Roos N, Berg T (1990) Intracellular transport of endocytosed proteins in rat liver endothelial cells. Biochem J 270:205-211

50. Hellevik T, Martinez I, Olsen R, Toh B-H, Webster P, Smedsrød B (1998) Transport of residual endocytosed products into terminal lysosomes occurs slowly in rat liver endothelial cells. Hepatology 28:1378-1389 